\title{
Time-Dependent Climate Impact of Utilizing Residual Biomass for Biofuels-The Combined Influence of Modelling Choices and Climate Impact Metrics
}

\author{
Johanna Olofsson (D)
}

check for updates

Citation: Olofsson, J. Time-Dependent Climate Impact of Utilizing Residual Biomass for Biofuels-The Combined Influence of Modelling Choices and Climate Impact Metrics. Energies 2021, 14, 4219. https://doi.org/10.3390/ en14144219

Academic Editor: Martin Junginger

Received: 11 June 2021

Accepted: 8 July 2021

Published: 13 July 2021

Publisher's Note: MDPI stays neutral with regard to jurisdictional claims in published maps and institutional affiliations.

Copyright: (C) 2021 by the author. Licensee MDPI, Basel, Switzerland. This article is an open access article distributed under the terms and conditions of the Creative Commons Attribution (CC BY) license (https:/ / creativecommons.org/licenses/by/ $4.0 /)$.
Environmental and Energy Systems Studies, Lund University, 22100 Lund, Sweden; johanna.olofsson@miljo.lth.se

\begin{abstract}
Understanding the influence of method choices on results in life-cycle assessments is essential to draw informed conclusions. As the climate impact of bioenergy remains a debated topic, the focus of this study is how the chosen temporal framing influences a comparison of the climate impact of utilizing residual biomass for biofuel production to that of leaving the biomass to decay. In order to compare the biofuel scenario to its corresponding reference scenario where biomass is left to decay, a variety of analytical approaches were used: using time-aggregated and time-dependent life-cycle inventories and climate-impact assessment methods, assuming biogenic carbon to be climate neutral or not, using metrics for cumulative or instantaneous climate impact, and with different time horizons. Two cases of residual biofuel feedstocks were assessed: logging residues from Norway spruce forest, and straw from wheat cultivation. Consideration of the studied method choices appears to be especially relevant for forest residual biomass, as illustrated by the ranges of parity times for logging residues (25 to 95 years), and the results which vary with the chosen climate-impact metric, time-horizon, and approach for including biogenic carbon. Illustrating the time-dependence of results can, in general, provide a better understanding of the climate impact of utilizing residual biomass for biofuels.
\end{abstract}

Keywords: forest residues; straw residues; bioenergy; life cycle assessment; biomass; bioethanol

\section{Introduction}

The body of literature on the application of life-cycle assessments (LCAs) to bioenergy has grown rapidly over the past couple of decades [1], as has the implementation of the knowledge gained from LCA in policies and industrial applications [2]. The use of LCA results as policy information in a direct way, such as in the European Union (EU) renewable energy directive (RED) [3], can however be seen as contrary to the widely acknowledged inability of LCA to produce definitive answers free from uncertainty and value choices [4,5].

The framing of time is one such potential value-laden aspect of LCA, not least when applied to biomass and biofuels. While policies such as the EU RED [3] rely on simplifications, including the use of the global warming potential over 100 years (GWP100), such choices are known to affect the outcomes of climate impact assessments. The representation of biomass life cycles and fluxes of greenhouse gases (GHG) over time is important to the resulting climate impact of biofuels [6-8], and the temporal framing of climate-impact results affect how different emissions with climate impact are weighed together into a single result in characterization [9-11]. These issues have led to suggestions to account for temporal aspects in LCA [12,13] and to avoid the assumption that biomass is inherently carbon neutral $[14,15]$ by including biogenic carbon dioxide $\left(\mathrm{CO}_{2}\right)$ and soil organic carbon (SOC) [16]. In addition, several climate-impact metrics and time horizons should be tested in each study in order to reveal the uncertainty arising from the choice of method used $[9,17-19]$. 
As the inherent uncertainties and value-choices related to temporal framings of biomass life-cycles and their climate impact in LCA cannot be eliminated, it becomes essential to investigate and illustrate how such choices affect results for biofuels. The modelling of biomass systems over time, and the resulting payback and parity times of bioenergy in terms of climate impact, vary significantly with method choices such as models for biomass growth and soil carbon, and the design of reference systems or baselines [6,20-27]. While many of these studies tend to rely on a single climate impact metric, the choice of metric has been shown to significantly affect climate impact results and conclusions for timber [28,29], trees grown for bioenergy purposes [29,30], and district heating from biogas and forest residual biomass [29]. By-products and residues have often been pointed out as potentially promising sources for bioenergy [31,32], and are promoted as feedstocks for advanced biofuels in current policy such as [3]. Therefore, it appears essential to also better understand how the combination of these method choices may influence the results for biofuels based on residual feedstock options.

\section{Aim and Scope}

The aim of this study is therefore to investigate how the temporal framing of both the biomass life-cycle and its climate impact influences the results for two biofuel cases with residual feedstock; bioethanol made from logging residues from Norway spruce (Picea abies (L.) H. Karst), and bioethanol made from wheat straw (Triticum L.). The present study focuses on the question of when, and with what methods, the biofuel production results in lower or higher climate impact than a reference scenario. In the reference scenario for each biofuel case, the residual biomass is assumed to be left at the forest or agricultural land, and the demand for transportation fuel is met with fossil fuels instead of biomass. The climate impact of both cases is assessed not only by taking into account the time dynamics of GHG-fluxes, but also by illustrating results over time to make visible the time dynamics of the resulting climate impact. While other environmental impact categories are relevant to these feedstocks, understanding their climate impact is essential if the biofuel is to be considered a potential part of a climate mitigation strategy.

The studied biofuel cases depart from the common forest management and agricultural systems as presently practiced in the Nordic countries, and specifically in Sweden, without assessing their sustainability or desirability from a wider perspective. This study thus differs from investigations into carbon balances of the entire forest and field, e.g., [33] by focusing on management options for residues only. The present forestry and agricultural practices have been debated from various sustainability perspectives $[34,35]$. How to manage the residues from these systems could thus be argued to be a secondary issue, but understanding the climate impact of utilizing the residues as biofuel feedstock and how it varies with method choices is nevertheless important, as current policy such as the EU RED already supports such practice.

\section{Materials and Methods}

\subsection{Biofuel and Reference Scenarios}

The biofuel production scenarios are based on the use of a defined amount of biomass: logging residues or wheat straw. Biomass production systems with longer rotation times have been shown to be particularly sensitive to the choice of aggregating GHG fluxes over time or allowing for time-dependent fluxes [30]. Therefore, the two cases with logging residues and wheat straw cover this divide: the rotation period of spruce forest in Sweden being approximately 100 years (depending on the geographical region), while wheat is cultivated on a yearly basis.

For comparison to the biofuel scenario, a functionally equivalent reference scenario is designed for each biomass type to (i) deliver the same functions as the biofuel scenario (fuel for transportation, heating, etc.), and to (ii) consider the counterfactual management of the same amount of residual biomass as in the biofuel scenario (Figures 1 and 2). The comparison of biofuel scenario and reference scenario thus addresses the question of 
whether it is preferable, from a climate impact perspective, to use the biomass for energy purposes, or to leave it in the forest or the agricultural field to decay, and instead rely on other sources of energy $[36,37]$. Since all the relevant functions of each biofuel production system are included here, no allocation or substitution is needed to deal with by-products from the bioethanol production process. This is in line with the allocation procedure stated in the ISO standard, which prioritizes system expansion in order to avoid allocation [38].

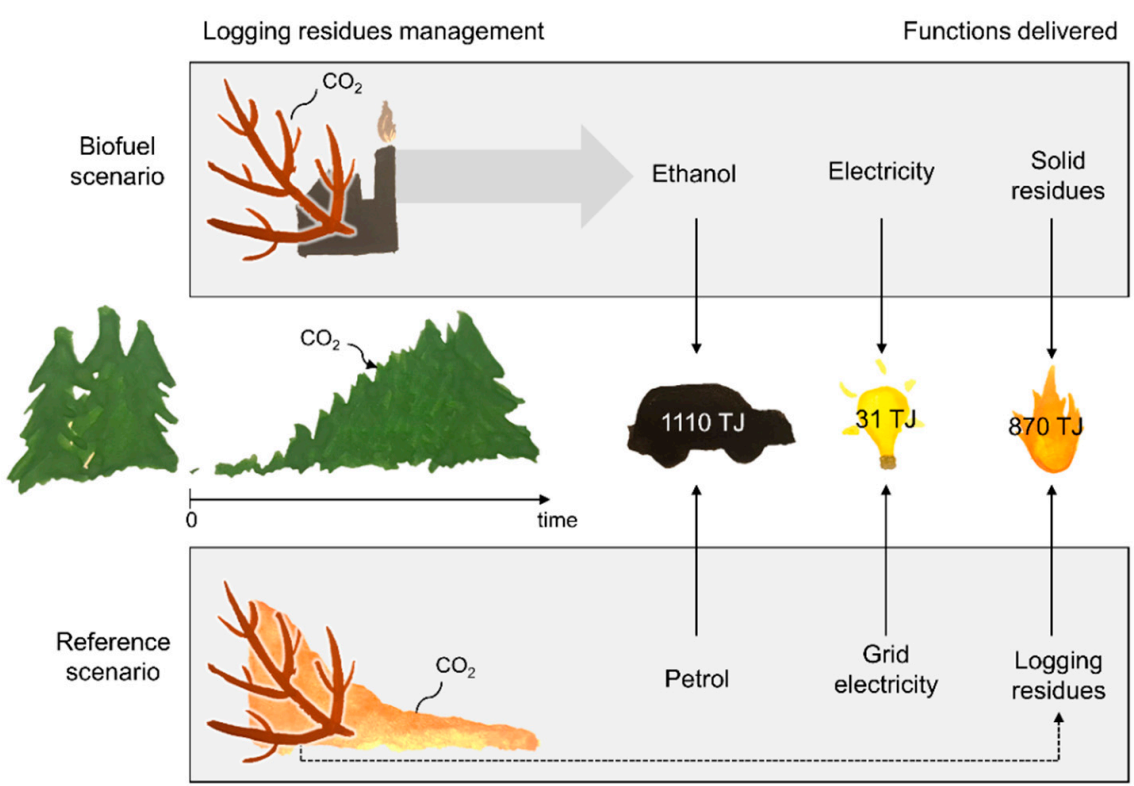

Figure 1. Schematic description of the biofuel scenario for logging residues (top), and the functionally equivalent reference scenario (bottom). The scenarios depart from the same forestry and deliver the same functions but differ in terms of how logging residues are managed (utilization for biofuel production or leave at the site) and how the functions are provided (from biomass, or fossil fuels and grid electricity). The broken arrow illustrates that a part of the residues is used for heating in the reference scenario. TJ: terajoules, $\mathrm{CO}_{2}$ : carbon dioxide.

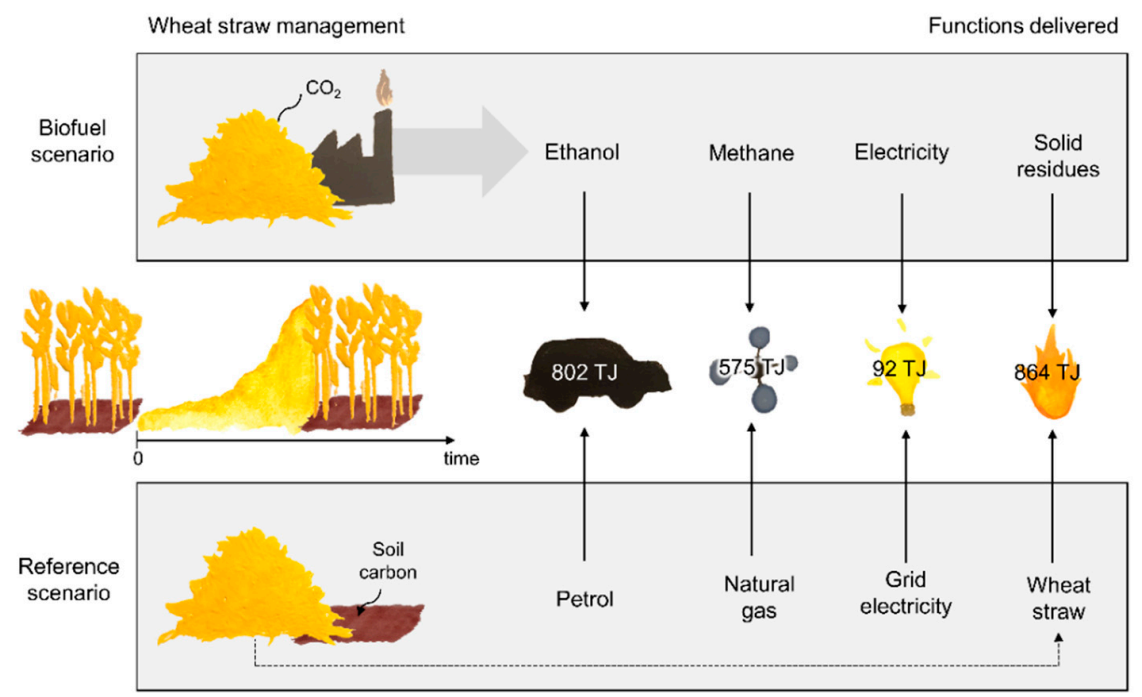

Figure 2. Schematic description of the biofuel scenario for wheat straw (top), and the functionally equivalent reference scenario (bottom). The scenarios depart from the same agricultural practice and deliver the same functions but differ in terms of how straw is managed (utilization for biofuel production or leave at the site) and how the functions are provided (from biomass, or fossil fuels and grid electricity). The broken arrow illustrates that a part of the straw is used for heating in the reference scenario. 
The inclusion of an alternative or counterfactual fate of biomass has been argued to be necessary before any conclusions can be drawn regarding a certain application [39], but the choice of reference scenario and its design are not self-evident [6,22]. According to the categorization presented in [40], the suitable reference scenario for the residues in this study is the "most likely alternative land or biomass use", which should be studied with the same temporal and spatial scope as the chosen system. The most likely alternative biomass use could be debated, especially when their future use has to be considered. A reference scenario that entails no use of the biomass for energy purposes is chosen, as the underlying question here is whether using the residues for energy purposes is beneficial or not in terms of climate impact.

A low- and high-emission case is considered for each biofuel and reference scenario. These represent the uncertainty and potential variation related to both the biomass systems (e.g., the decay rate of logging residues, the contribution of straw to soil carbon), and the data applied in the life-cycle inventory phase (e.g., GHG emissions from fossil fuels). Thus, the results should be seen as indicative spans, rather than exact measures. The life-cycle inventory data applied are presented in Supplementary Materials S1. The GHG emissions data applied are primarily chosen from $[41,42]$ which are used for calculations in line with EU GHG emissions regulations.

\subsubsection{Logging Residues}

The biofuel scenario considers the use of 200,000 tonnes ( $t$ ) dry matter (DM) logging residues yearly and produces ethanol (1110 TJ, terajoules), solid residues for heating (870 TJ), and electricity (31 TJ, Figure 1). The ethanol production process has been described previously $[43,44]$ and the case " $\mathrm{B}$ " from these studies, with integrated enzyme and ethanol production in a Swedish plant, was chosen for the biofuel scenario. After steam pretreatment of the biomass, a pretreated liquid fraction is supplemented with molasses to increase the sugar content and is used as feed for enzyme fermentation. Cellulase enzymes are produced using a mutant of Trichoderma reesei, employing the whole crude fermentation broth of the fungus in the saccharification step. This ethanol production process is not commercially available, and data refer to lab-scale results. While lab-scale data can be inadequate for assessing impacts of future large-scale commercial production [45], it is acceptable to this study where the focus is on implications of choices related to the temporal framing of carbon cycling and climate impact. Other available data rely on other uncertain assumptions and applications which cannot be deemed technologically mature, for instance, the production and dosage of purchased cocktails with cellulase enzymes [44,46,47].

Logging residues are assumed to be harvested at two locations in Sweden [48] for the high-emission and low-emission cases. Further details and aggregated results for the ethanol plant and the harvest of residues are shown in Supplementary Materials S1.

In the reference scenario, fossil petrol is assumed to be used for transportation instead of bioethanol (Figure 1). The biofuel scenario produces a solid residue that is assumed to be used for heat production. A realistic alternative choice of heating fuel could be logging residues, and the reference scenario, therefore, includes the use of part of the logging residues (45,000 t yearly) as fuel to generate the corresponding amount of heat, while the rest of the biomass $(155,000 \mathrm{t})$ is assumed to be left at the forest site. As the biofuel scenario includes the production of excess electricity, the same amount of grid electricity is assumed to be produced in the reference scenario.

\subsubsection{Straw}

The biofuel scenario considers the use of 200,000 t DM straw yearly and produces bioethanol (802 TJ), methane (575 TJ), solid residues for heating ( $864 \mathrm{TJ})$, and electricity (92 TJ, Figure 2). The design of the biofuel plant and relevant data for harvest and transport of straw are taken from [49]. The Swedish plant includes the fermentation of hexose sugars to ethanol and anaerobic microbial production of methane from the pentose-containing 
liquid residue after pre-treatment together with the stillage. Also, for this bioethanol process, it should be pointed out that the plant is not commercially available. The aggregated results for the plant and the harvest of straw are shown in Supplementary Materials S1 along with further details on the combined ethanol and methane production.

In the reference scenario, the counterparts to bio-based transportation fuel, gas, and electricity are petrol, natural gas, and grid electricity (Figure 2). In order to provide a function corresponding to the solid residue from bioethanol production, which could be used as fuel for heating, the reference scenario includes the harvest of 46,000 t DM straw yearly (leaving 154,000 $t$ at the field).

\subsection{Temporal Considerations}

The temporal considerations explored in this study can be seen as three-fold: (i) representation of the life-cycle over time, including time-dependence of GHG emissions and uptake, (ii) the time horizon considered, and iii) climate-impact assessment over time (see Section 2.3). The representation of the life-cycle inventories follows two distinct modelling approaches. Calculations of climate impact are made using a time-aggregated inventory, in which all the relevant fluxes of GHGs are represented at one point in time, and using a time-dependent inventory, including yearly GHG fluxes over 100 years (Table 1). Timeaggregated inventories are coupled to time-aggregated results and characterization factors for climate impact metrics (GWP, GTP-global temperature change potential, $\mathrm{GWP}_{\mathrm{bio}}$ ), and time-dependent inventories with time-dependent climate-impact assessment approaches (AGWP — absolute global warming potential, AGTP—absolute global temperature change potential, see Section 2.3).

Table 1. Analytical approaches and assumptions used in this study, including type of climate impact metric, setup of life-cycle inventories, and assumption for biogenic $\mathrm{CO}_{2}$ (carbon dioxide).

\begin{tabular}{cccccc}
\hline \multirow{2}{*}{$\begin{array}{c}\text { Climate-Impact } \\
\text { Metric }\end{array}$} & \multicolumn{2}{c}{ Life-Cycle Inventories } & \multicolumn{2}{c}{ Biogenic $\mathrm{CO}_{2}$} & \multicolumn{2}{c}{ Climate Impact Metric } \\
Time-Aggregated & Time-Dependent & Climate Neutral & Included & Cumulative & Instantaneous \\
\hline GWP & $\mathrm{x}$ & $\mathrm{x}$ & $\mathrm{x}$ & $\mathrm{x}$ & $\mathrm{x}$ \\
GTP & $\mathrm{x}$ & & $\mathrm{x}$ & $\mathrm{x}$ \\
$\mathrm{GWP}_{\mathrm{bio}}$ & $\mathrm{x}$ & $\mathrm{x}$ & $\mathrm{x}$ & $\mathrm{x}$ \\
AGWP & & $\mathrm{x}$ & $\mathrm{x}$ & $\mathrm{x}$ \\
AGTP & & & & \\
\hline
\end{tabular}

${ }^{\text {a }}$ GWPbio factors apply only to biogenic $\mathrm{CO}_{2}$ emissions, and regular GWP factors are applied to other emissions. GWP: global warming potential, GTP: global temperature change potential, AGWP: absolute global warming potential, AGTP: absolute global temperature change potential.

The temporal resolution of the time-dependent inventories is per year, and therefore all the GHGs emitted and sequestered during the preceding year are assumed to be emitted as a pulse emission at the beginning of each year. At the beginning of the first year, all the GHG emissions related to the production of fuels and other products, as well as combustion emissions, are emitted. The GHG fluxes during the following years consist of $\mathrm{CO}_{2}$ sequestration in growing biomass and $\mathrm{CO}_{2}$ emissions from decaying biomass.

The time horizon considered is 100 years but results for a 20-year time horizon are also reported. The 100-year time horizon entails monitoring the GHG fluxes and the resulting climate impact for 100 years. This means that emissions occurring in the first year have a climate impact during the following 100 years, but emissions in the 50th year (in the time-dependent inventories), for example, only have a climate impact for the remaining 50 years. Such an approach has been discussed as a consistent way of dealing with timedependent characterization based on time-dependent inventories $[12,50]$. The underlying rationale can be an interest in the climate impact during the coming 100 years, despite the fact that the production systems considered will have a climate impact even longer into the future. While time-dependent climate-impact characterization allows for reporting over any timescale, the time horizon of 100 years allows for comparison with the results from other metrics, such as the commonly applied GWP100. 


\subsubsection{Time-Dependent Carbon Flux in Biomass Life Cycles}

When the cycling of $\mathrm{CO}_{2}$ between the biosphere and atmosphere over time is considered, biogenic $\mathrm{CO}_{2}$ which temporarily resides in the atmosphere will have a climate impact, even in a biomass system that is carbon-neutral over time. In the time-aggregated inventories, the carbon flux of the biomass cycle is effectively aggregated over 100 years, and biogenic $\mathrm{CO}_{2}$ is therefore assumed to be climate-neutral since the same amount of carbon is sequestered from, and released to, the atmosphere. This is not the case when using $\mathrm{GWP}_{\text {bio }}$ factors specifically for biogenic $\mathrm{CO}_{2}$ (see Section 2.3.1), in which a climate impact of biogenic $\mathrm{CO}_{2}$ is included. In the time-dependent inventories, however, all fluxes of GHGs are considered on a yearly basis, and no assumption of climate neutrality is made for biogenic $\mathrm{CO}_{2}$ (Table 1).

The way in which the life cycle of biomass is described over time, starting from harvest and combustion, and followed by the regeneration of biomass, or starting from sowing and growth, followed by harvest and combustion, can be decisive for the interpretation of the climate impact from biomass, especially for long-rotation biomass [6]. This choice has been referred to as the chicken-egg dilemma [51], and suggestions for overcoming it include landscape-level methods that include the different phases of biomass growth [6]. This issue is explored using two different approaches for the logging residues scenarios in this study: by considering biofuel production to be a single event in the first year of the study and considering it to be a continuous yearly activity over 20 years. The latter approach entails 20 forest stands that are managed identically, but where one stand is logged every year, and the logging residues are either harvested (biofuel scenario) or left at the site (reference scenario). The choice of 20 years is arbitrary but indicates how the assumption regarding the start of the life-cycle can influence the outcome and interpretation of the resulting climate impact.

The dilemma of how the long-rotation biomass life-cycle is described over time is, however, not decisive to the conclusions that can be drawn from the comparative approach used here, in which forestry and forest growth are assumed to be identical in the biofuel and the reference scenario, and focus is on the management of logging residues (see Section 3.1.3).

\subsubsection{Logging Residues}

- Forest regrowth and carbon sequestration

The same amount of carbon available in the logging residues considered is assumed to be sequestered in the tops and branches of a regrowing identical forest during the assumed rotation period of 100 years. The shape of the carbon sequestration distribution over this period is equal to the shape of the Chapman-Richards function using parameters corresponding to a slow-growing boreal forest with 100 years' rotation time [52,53] (see Supplementary Materials S1).

\section{- Decay of logging residues}

When logging residues are left at the forest site in the reference scenario, a large fraction is assumed to decay, and as a consequence, its carbon content is released into the atmosphere as $\mathrm{CO}_{2}$. The collected logging residues in this study are assumed to consist of branches, as this is the primary forest biomass type considered for further processing into bio-based chemicals and fuels. Their decay is estimated using both a simplistic exponential decay model [54] and the Q-model [55] (see Supplementary Materials S1) since the decay rate is both uncertain and constitutes a difference between the biofuel and the reference scenario, which affects their comparison [27]. The exponential and the Q-model differ in terms of the rate of the biomass decay, and thus the fraction of logging residues that decay within 100 years. The Q-model also includes a time lag before all the biomass in branches is exposed to decay mechanisms, which slightly alters the shape of the decay curve over time. The exponential decay model is used for the high-emission case of the reference scenario, and the Q-model is used for the low-emission case of the reference scenario. Other models 
can be used to estimate the decay of logging residues [54], but the above two models are chosen as they are considered fit for the purpose of this study to include an indication of uncertainty and variation.

- Soil organic carbon

Since a fraction of the carbon in biomass left to decay can add to the long-term stable pool of carbon in the soil, harvesting logging residues may lead to a reduction in the carbon stored as soil organic carbon (SOC) [23]. The exact behaviour of SOC, other soil characteristics, and subsequent forest growth can however be difficult to determine [56-58]. Here the carbon content of the fraction of logging residues that do not decay within 100 years are assumed to contribute to SOC in the reference scenario. This means that no specific modelling of SOC behaviour is made for the selected geographical regions, and instead, the contribution to SOC is determined by the decay rate of branches.

\subsubsection{Straw}

The carbon flux from sequestration in the growth of straw and release from its consequent decay are both assumed to occur within a single year. Therefore, the calculations based on time-dependent inventories do not take into account a climate impact from the temporary stay of $\mathrm{CO}_{2}$ in the atmosphere. Instead, it is only the calculations with the $\mathrm{GWP}_{\text {bio }}$ metric that include such an impact (see Table 2).

- Soil organic carbon

The straw left on site in the reference scenario is assumed to decay and to partly contribute to stable SOC in the soil. Since the decay of straw is assumed to be immediate (within one year), the effects of straw harvest on SOC are based on humification coefficients, with different assumptions for the low- and high-emission cases. For the high-emission case, a low contribution is assumed from straw to stable SOC based on [59]. The chosen case ("technical potential", production area 3) represents the maximum possible harvest of straw and the production area in Sweden where the loss of SOC following straw harvest is considered highest. More specifically, the humification coefficient is assumed to be 0.0275 , which means that $2.75 \%$ of the carbon in non-harvested straw biomass is assumed to contribute to stable SOC. For the low-emission case, the straw was instead assumed to make a higher contribution to stable SOC, with the humification coefficient of 0.15 [49], which is based on previous understandings and expert recommendations for SOC preservation [59]. It is thus assumed in the calculations that there is no loss of SOC when the straw is harvested, but there is a build-up of SOC when the straw is left at the agricultural site. The effect on SOC following straw harvest is therefore reflected in the difference between the biofuel and the reference scenario. Other study designs can however be argued for [60] and therefore results must be interpreted with the precise comparative setup in mind.

\subsection{Climate-Impact Assessment}

Although it is known that GHGs impact the Earth's climate, it is not self-evident how the effects should be most accurately and usefully accounted for in environmental assessments. Both time-aggregated and time-dependent approaches are used in this study to account for the climate impact of emissions of the well-mixed GHGs $\mathrm{CO}_{2}, \mathrm{CH}_{4}$, and $\mathrm{N}_{2} \mathrm{O}$ (Table 2). The time-aggregated approaches include the GWP and GTP metrics, calculated with characterization factors (Table 2), and each considering a 20-year and a 100-year time horizon. The time-dependent approaches include the AGWP and AGTP.

As a further differentiation, the included climate-impact assessment metrics are either instantaneous (GTP and AGTP) or cumulative (GWP and AGWP) [18] (Table 1). Instantaneous metrics describe an impact at a certain point in time, for example, in 100 years from now, while cumulative metrics describe the impact up until a certain point in time. As GHGs emitted to the atmosphere naturally decay (or otherwise disperse), whether or not the initial impact is considered at a later point in time is an important divider. 


\subsubsection{Time-Aggregated Approaches}

The starting point for quantifying climate impact in all the metrics used in the present study is the contribution from GHG emissions to a change to the Earth's energy balance, also known as radiative forcing (RF) [61]. RF can be seen as the first step after GHG emissions in the cause-effect chain of resulting climate change [62]. Building on the concept of RF, the most common climate-impact metric used in LCA studies is GWP, which describes the cumulative RF resulting from a pulse emission of a substance compared to the cumulative RF from a pulse emission of an equal mass of $\mathrm{CO}_{2}$ [61]. GWP100 denotes the integration of RF over a time horizon of 100 years, while GWP20 denotes the integral over a 20-year time horizon. Despite the terminology, the concept of GWP has no explicit connection to warming but is rather a cumulative forcing index [61]. The GTP metric, in contrast, describes the change in mean surface temperature at a certain point in time resulting from a pulse emission of a substance, compared to the change in temperature at the same point in time resulting from a pulse emission of an equal mass of $\mathrm{CO}_{2}$ [61]. The connection to temperature change in GTP is achieved by including the climate response which follows from RF-based on a climate model [63]. The GTP concept thus represents an actual climate impact more than RF or GWP, but the uncertainties increase as one moves down the cause-effect chain [62].

Table 2. Characterization factors for greenhouse gas emissions and climate-change impact assessment methods.

\begin{tabular}{|c|c|c|c|c|c|}
\hline & $\mathrm{CO}_{2}$ & $\mathrm{CH}_{4}$ & $\mathbf{N}_{2} \mathrm{O}$ & Comment & Source \\
\hline GWP100 & 1 & 34 & 298 & \multirow{4}{*}{ With climate-carbon feedbacks ${ }^{a}$} & \multirow{4}{*}[61]{} \\
\hline GWP20 & 1 & 86 & 268 & & \\
\hline GTP100 & 1 & 11 & 297 & & \\
\hline GTP20 & 1 & 70 & 284 & & \\
\hline \multirow{3}{*}{$\mathrm{GWP}_{\text {bio }} 100^{\mathrm{b}}$} & 0.43 & & & Rotation 100 years $\left(\mathrm{LR}^{\mathrm{c}}\right)$ & {$[64]$} \\
\hline & 0.53 & & & Rotation 100 years $\left(\mathrm{LR}^{\mathrm{c}}\right)$ and $75 \%$ harvest rate ${ }^{\mathrm{d}}$ & [65] \\
\hline & 0 & & & Rotation 1 year (WS e) & [64] \\
\hline \multirow{3}{*}{$\mathrm{GWP}_{\mathrm{bio}} 20^{\mathrm{b}}$} & 0.96 & & & Rotation 100 years $\left(\mathrm{LR}^{\mathrm{c}}\right)$ & [64] \\
\hline & 1.13 & & & Rotation 100 years $\left(\mathrm{LR}^{\mathrm{c}}\right)$ and $75 \%$ harvest rate ${ }^{\mathrm{c}}$ & [65] \\
\hline & 0.02 & & & Rotation 1 year (WS e) & [64] \\
\hline
\end{tabular}

a The IPCC provides GWP and GTP factors with and without climate-carbon feedbacks (cc fb). Feedback mechanisms are always included for $\mathrm{CO}_{2}$, and therefore the use of factors including climate-carbon feedbacks for other climate forcers has been recommended [17,18]. Following these recommendations, factors including climate-carbon feedbacks are applied. The slight difference in results obtained by instead applying factors which exclude them is presented in Supplementary Materials S1. ${ }^{b}$ Based on the option with full impulse response function (FIRF), which considers both the terrestrial biosphere and the oceans as $\mathrm{CO}_{2}$ sinks, and models the impulse response function for $\mathrm{CO}_{2}$ according to the Bern $2.5 \mathrm{CC}$ model, consistent with the IPCC fourth assessment report. ${ }^{\mathrm{c}}$ Applied to logging residues (LR) ${ }^{\mathrm{d}}$ Applied to biogenic $\mathrm{CO}_{2}$ in the reference scenario for logging residues. The scenario is chosen in which $75 \%$ of aboveground residues are harvested (except for foliage, for which only $25 \%$ is removed) and no harvest of belowground residues occurs [65]. ${ }^{\mathrm{e}}$ Applied to wheat straw (WS). $\mathrm{CH}_{4}$ : methane, $\mathrm{N}_{2} \mathrm{O}$ : nitrous oxide.

The characterization factors used to apply the time-aggregated climate-impact metrics to time-aggregated inventories in this study are listed in Table 2.

- Characterization factors for biogenic $\mathrm{CO}_{2}$

In the calculations that apply the time-aggregated climate-impact metrics, the biogenic $\mathrm{CO}_{2}$ is assumed to be climate neutral except in calculations with the $\mathrm{GWP}_{\text {bio }}$ factors (Table 2). These factors are applied to biogenic $\mathrm{CO}_{2}$, and they are based on the assumption that the biogenic carbon cycle starts with biomass harvest and a $\mathrm{CO}_{2}$ pulse emission, and the same type of biomass is assumed to be immediately replanted and regrown [64]. The amount of $\mathrm{CO}_{2}$ first emitted is assumed to be sequestered in regrowing biomass over the rotation period, creating a "carbon flux neutral" process. The climate impact arising from biogenic $\mathrm{CO}_{2}$ emissions occurs when biogenic $\mathrm{CO}_{2}$ is temporarily stored in the atmosphere.

Further elaborated $\mathrm{GWP}_{\text {bio }}$ factors for forest biomass which take into account the decay of unharvested residues at the forest site are available [65]. Approximately 78\% of the residues are left at the forest site to decay in the reference scenario in this study (see Section 2.1.1), and therefore the elaborated factors are applied to this scenario. The 
factors for the case with a harvest of $75 \%$ of aboveground biomass, except for foliage of which $25 \%$ is harvested, and no harvest of belowground biomass, are chosen (Table 2). The use of this $\mathrm{GWP}_{\text {bio }}$ factor means that the total amount of $\mathrm{CO}_{2}$ emitted from the decay of residues left in the forest over 100 years is not explicitly included in calculations, however, the decay emissions are implicitly included in the $\mathrm{GWP}_{\text {bio }}$ method. This approach thus differs from all other calculations where carbon mass balances form the basis for biogenic $\mathrm{CO}_{2}$ emissions.

Other similar metrics for biogenic $\mathrm{CO}_{2}$ are available [16] and may yield different results [66]. As the biofuel scenarios are compared to explicit reference scenarios in the present study, metrics that include fossil alternatives to bioenergy, or continued growth of an otherwise unharvested forest, are not applied [67].

\subsubsection{Time-Dependent Approaches}

Time-dependent approaches to climate-change accounting allow for emissions at different points in time. Based on time-dependent inventories, the atmospheric decay of each pulse emission of a GHG is taken into account by an impulse response function, so that the amount of each GHG in the atmosphere at a certain time is the sum of the fractions remaining from previous emissions.

The time-dependent climate-impact approaches included here use AGWP and AGTP, on which GWP and GTP characterization factors are built. The AGWP is defined as the RF of a $1 \mathrm{~kg}$ pulse emission of gas, integrated over a certain time horizon. Similarly, the AGTP indicates the change in surface temperature at a certain point in time as a consequence of emission and has also been termed mean global surface temperature change, $\Delta \mathrm{Ts}[25,37,68]$. In the present study, the metrics of AGWP and AGTP are applied to all relevant GHG emissions in the biofuel and the reference scenarios, and not only to $1 \mathrm{~kg}$ pulse emissions of GHGs. Both AGWP and AGTP can be calculated over time, and for any time horizon. Their results are given here over a time period of 100 years in order to facilitate comparison to the chosen time-aggregated metrics. Following this time-dependent approach to LCA is similar to applying dynamic characterization factors [69,70], but the results are presented differently as in this case, the climate impact is given not only as a single number but also as impact over time.

The equations and relevant parameter values for impulse response functions, AGWP, and AGTP used in this study follow the IPCC 5th assessment report [61], and are given in Supplementary Materials S1. The practical execution of the calculations was further aided by the Excel spreadsheet made available through Cooper et al. [29,71].

\section{Results and Discussion}

\subsection{Logging Residues}

The time-aggregated results indicate that both the biofuel and the reference scenario for logging residues may be preferable from a climate impact point of view, depending on the modelling approach used (Table 3), and the time-dependent results indicate that the question of a preferable scenario changes with time (Figures 3 and 4). Several of the tested approaches have the possibility to change the outcome of climate impact comparison: biogenic $\mathrm{CO}_{2}$, both its inclusion and the method chosen for its inclusion (using ready-made characterization factors or in time-dependent inventories), the choice of time-horizon, the choice of climate-impact metric (AGWP or AGTP), and choices related to system design and the data used (as indicated by differences between low- and high-emission cases). 
Table 3. Climate impact from handling of forest residues in the biofuel scenario and the reference scenario. The climate impact is calculated for utilization of 200,000 tonnes ( $t$ ) DM (dry matter) logging residues, except in the cases of AGWP and AGTP calculations of 20 years' production (utilization of 200,000 t DM logging residues each year for 20 consecutive years). Dark shading marks the scenario that results in higher climate impact, and light shading means that the climate impact of the two scenarios overlap.

\begin{tabular}{|c|c|c|c|c|c|c|}
\hline \multirow{2}{*}{ Time Horizon } & \multirow{2}{*}{ Climate-Impact Assessment } & \multirow{2}{*}{ Unit } & \multicolumn{2}{|c|}{ Biofuel Scenario } & \multicolumn{2}{|c|}{ Reference Scenario } \\
\hline & & & Low Case & High Case & Low Case & High Case \\
\hline \multirow{7}{*}{100 years } & GWP & Mt $\mathrm{CO}_{2}$-eq. & 16 & 19 & 91 & 100 \\
\hline & GTP & $\mathrm{Mt} \mathrm{CO}_{2}$-eq. & 15 & 18 & 90 & 100 \\
\hline & $\mathrm{GWP}_{\text {bio }}$ & $\mathrm{Mt} \mathrm{CO}_{2}$-eq. & 180 & 190 & 140 & 150 \\
\hline & AGWP (1 year's production) & $\mathrm{W} \times$ year $\times \mathrm{m}^{-2}$ & $1.9 \times 10^{-5}$ & $1.9 \times 10^{-5}$ & $1.9 \times 10^{-5}$ & $2.2 \times 10^{-5}$ \\
\hline & AGWP (20 years' production) & $\mathrm{W} \times$ year $\times \mathrm{m}^{-2}$ & $3.4 \times 10^{-4}$ & $3.4 \times 10^{-4}$ & $3.4 \times 10^{-4}$ & $3.9 \times 10^{-4}$ \\
\hline & AGTP (1 year's production) & $\mathrm{K}$ & $5.0 \times 10^{-10}$ & $2.2 \times 10^{-9}$ & $2.7 \times 10^{-8}$ & $4.1 \times 10^{-8}$ \\
\hline & AGTP (20 years' production) & K & $6.6 \times 10^{-8}$ & $1.0 \times 10^{-7}$ & $6.0 \times 10^{-7}$ & $9.0 \times 10^{-7}$ \\
\hline \multirow{7}{*}{20 years } & GWP & $\mathrm{Mt} \mathrm{CO}_{2}$-eq. & 16 & 19 & 94 & 110 \\
\hline & GTP & $\mathrm{Mt} \mathrm{CO}_{2}$-eq. & 16 & 19 & 93 & 110 \\
\hline & $\mathrm{GWP}_{\text {bio }}$ & $\mathrm{Mt} \mathrm{CO}_{2}$-eq. & 340 & 390 & 190 & 200 \\
\hline & AGWP (1 year's production) & $\mathrm{W} \times \operatorname{year} \times \mathrm{m}^{-2}$ & $9.8 \times 10^{-6}$ & $9.9 \times 10^{-6}$ & $7.1 \times 10^{-6}$ & $7.8 \times 10^{-6}$ \\
\hline & AGWP (20 years' production) & $\mathrm{W} \times$ year $\times \mathrm{m}^{-2}$ & $1.0 \times 10^{-4}$ & $1.0 \times 10^{-4}$ & $6.1 \times 10^{-5}$ & $7.0 \times 10^{-5}$ \\
\hline & AGTP (1 year's production) & $\mathrm{K}$ & $2.6 \times 10^{-7}$ & $2.6 \times 10^{-7}$ & $2.2 \times 10^{-7}$ & $2.4 \times 10^{-7}$ \\
\hline & AGTP (20 years' production) & $\mathrm{K}$ & $4.0 \times 10^{-6}$ & $4.0 \times 10^{-6}$ & $2.5 \times 10^{-6}$ & $2.9 \times 10^{-6}$ \\
\hline
\end{tabular}
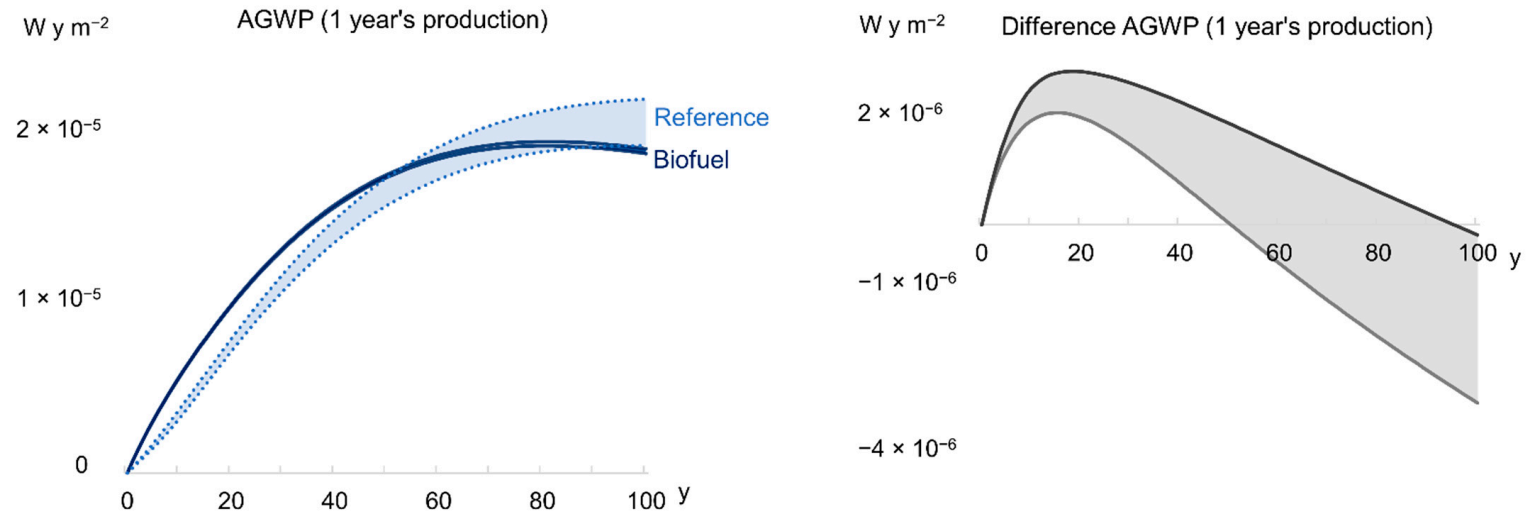

$-4 \times 10^{-6}$

W y m $\mathrm{m}^{-2} \quad$ AGWP (20 years' production)

$5 \times 10^{-4}$

W y m ${ }^{-2}$ Difference AGWP (20 years' production)

$6 \times 10^{-5}$
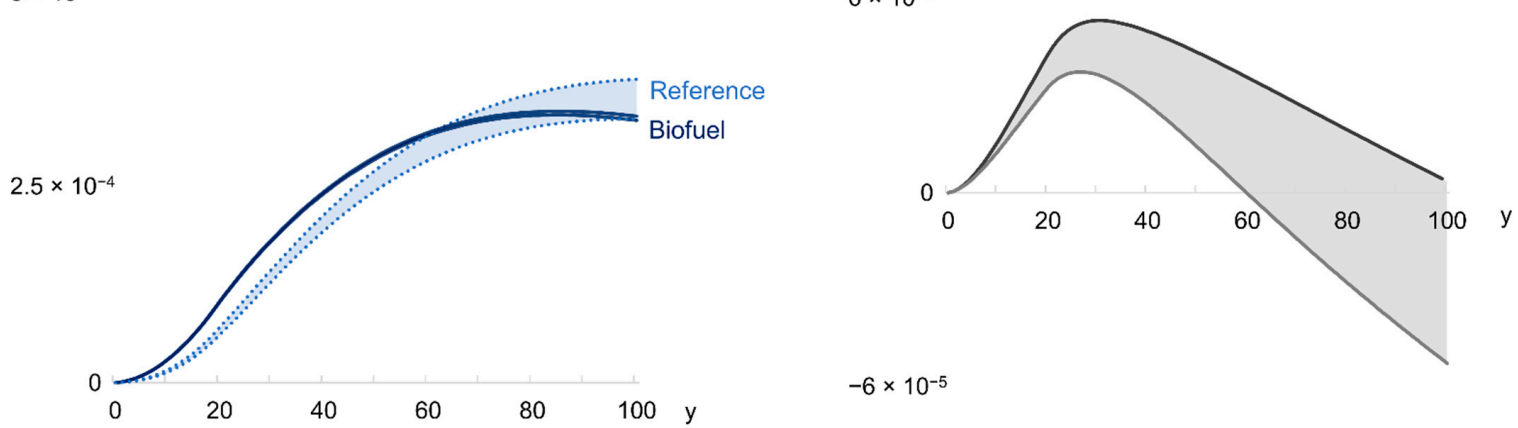

$-6 \times 10^{-5}$

Figure 3. Climate impact in terms of AGWP resulting from handling of logging residues in the biofuel scenario and the reference scenario. The graphs showing climate impact of one year's production correspond to utilization of 200,000 $\mathrm{t} D \mathrm{M}$ logging residues, and the graphs showing 20 years of production correspond to utilization of 200,000 $\mathrm{t}$ DM logging residues each year for 20 consecutive years. On the right-hand side, the shaded regions show the difference in results for the biofuel and the reference scenario. The upper line shows the climate impact of the high-emission case of the biofuel scenario, with the impact of the low-emission case of the reference scenario subtracted. The lower line shows the climate impact of the low-emission case of the biofuel scenario, with the impact of the high-emission case of the reference scenario subtracted. 
K

$3 \times 10^{-7}$

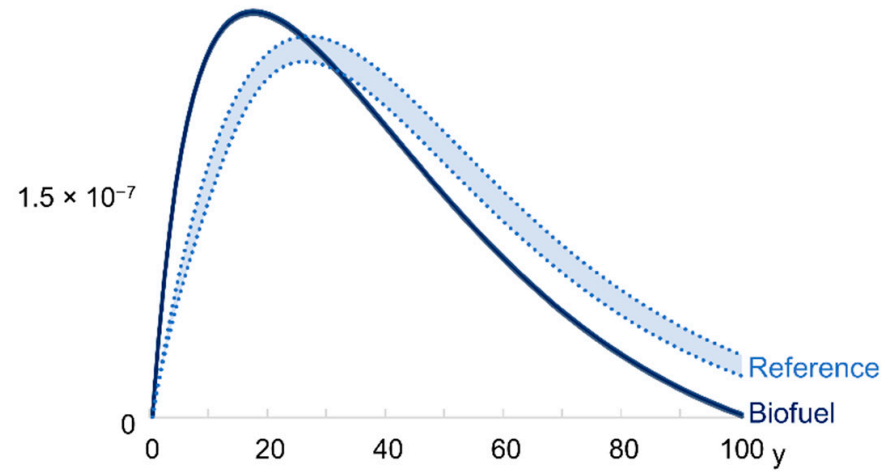

$\mathrm{K}$

$6 \times 10^{-6}$

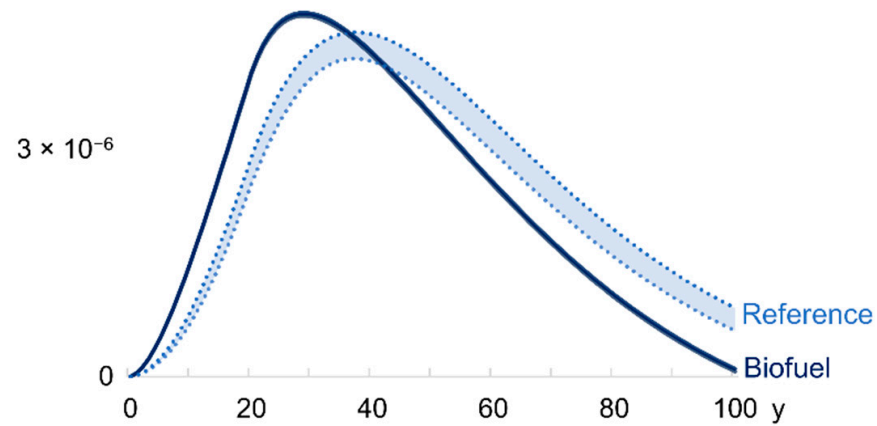

$\mathrm{K}$

Difference AGTP (1 year's production)

$1.2 \times 10^{-7}$

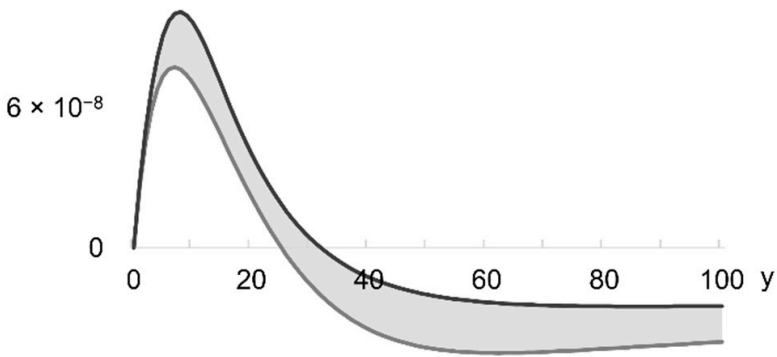

$-6 \times 10^{-8}$

$\mathrm{K}$

Difference AGTP (20 years' production)

$2 \times 10^{-6}$

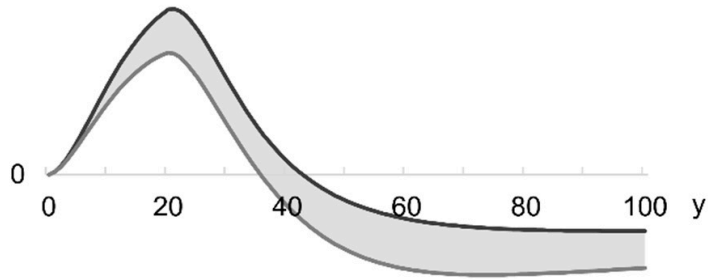

$-2 \times 10^{-6}$

Figure 4. Climate impact in terms of AGTP resulting from handling of logging residues in the biofuel scenario and the reference scenario. The graphs showing climate impact of one year's production correspond to utilization of 200,000 $\mathrm{t} D \mathrm{M}$ logging residues, and the graphs showing 20 years of production correspond to utilization of 200,000 $\mathrm{t}$ DM logging residues each year for 20 consecutive years. On the right-hand side, the shaded regions show the difference in results for the biofuel and the reference scenario. The upper line shows the climate impact of the high-emission case of the biofuel scenario, with the impact of the low-emission case of the reference scenario subtracted. The lower line shows the climate impact of the low-emission case of the biofuel scenario, with the impact of the high-emission case of the reference scenario subtracted.

\subsubsection{Biogenic $\mathrm{CO}_{2}$ and Time-Dependent GHG Flux}

The results consistently show that harvesting logging residues for bioethanol production is preferable from a climate impact perspective when biogenic $\mathrm{CO}_{2}$ is considered climate neutral. This includes calculations with GWP100, but also GWP20, GTP100, and GTP20. All the results that include biogenic $\mathrm{CO}_{2}$ (i.e., calculations with $\mathrm{GWP}_{\mathrm{bio}}$, $\mathrm{AGWP}$, and AGTP) do not paint the same picture: the biofuel scenario results in lower climate impact in calculations with AGTP while the reference scenario has lower results with the $\mathrm{GWP}_{\text {bio }}$ metric, and results for AGWP depend on the time horizon (Table 3). The inclusion of biogenic $\mathrm{CO}_{2}$ or time-dependent modelling of GHG fluxes is thus not enough to conclude on a preferable scenario from a climate impact perspective.

Both the inclusion of biogenic $\mathrm{CO}_{2}$ and the method for its inclusion can affect the comparison of the biofuel and reference scenario for logging residues. The results of the present study show that applying $\mathrm{GWP}_{\text {bio }}$ factors to residual forest biomass does not reflect the complexity of the possible conclusions illustrated by the time-dependent results, even when using only GWP (or AGWP) as the climate-impact metric. This could potentially be explained by the lack of an explicit $\mathrm{GWP}_{\text {bio }}$ factor for the emissions from the decay of 
logging residues in the reference scenario, or by differences in the models used to calculate the rate of decay of logging residues and forest growth.

\subsubsection{Instantaneous and Cumulative Impact over Time}

The AGWP and AGTP results presented over time (Figures 3 and 4) can potentially help to explain the various outcomes in Table 3 . The results show an initially higher climate impact for the biofuel scenario, in terms of both AGWP and AGTP, in agreement with the findings of previous studies. When applying different climate-impact metrics, the results for AGTP show a lower climate impact in the biofuel scenario in the long term (100 years), while the results for AGWP show a slightly, but not significantly, lower climate impact in the biofuel scenario (compare Figure 3 to Table 3 ). The difference in long-term results from a cumulative metric such as AGWP, and an instantaneous metric such as AGTP, is not surprising but demonstrates the importance of the choice of assessment method.

The question of whether the biofuel scenario is preferable from a climate perspective thus appears inadequate as the answer varies with time, and with the chosen metric for climate change. GWP has been argued inadequate for assessing long-term impact due to its cumulative nature $[9,17,72]$, and when all GWP results are interpreted as indicating short-term climate change, and GTP results as indicating long-term climate change, the present results more clearly lean towards favouring the reference scenario in the short term, as long as biogenic $\mathrm{CO}_{2}$ is included, and the biofuel scenario in the long term.

\subsubsection{Parity Times}

The point in time at which the climate impact of the biofuel scenario is the same as that of the reference scenario, the so-called parity-time, ranges from approximately 50 to 95 years for AGWP (Figure 3), and from approximately 25 to 30 years for AGTP (Figure 4). While these parity times are longer if biofuel production is seen as a reoccurring event over 20 years, the result in terms of which scenario results in the lowest climate impact is unchanged (Table 3). The timing of the biomass life-cycle, starting with growth or harvest, is thus not decisive to the comparison of biofuel and reference scenario in this study. This can be explained by the comparative setup: assuming that biofuel is produced from forest biomass in 20 years means that carbon is first sequestered for 19 years, which changes the absolute GHG balance for that specific biomass and biofuel, but as the same forest growth and management (growth followed by harvest) are assumed in the reference scenario, the comparison between scenarios would not be affected. Instead, the parity times indicated for forest residual bioenergy correspond to the immediate release of carbon, as compared to the slow release of the same carbon through the decay of biomass at the forest. This is characteristic of residual biomass, since it is a consequence of the assumption that the forest is managed and logged in the same way in the scenarios, apart from the harvest of residues.

\subsection{Straw}

In contrast to the results for forest-based bioethanol, the biofuel scenario considering ethanol made from wheat straw results in a lower climate impact than the reference scenario in all cases studied (Table 4 and Figure 5). The choice of time horizon and climate-impact assessment approach does not significantly affect the interpretation of the results, as the biofuel scenario results in lower climate impact for all assumptions. As the results for climate impact over time show, there is no parity-time or breaking point at which the biofuel scenario becomes preferable from a climate-impact perspective. Instead, the biofuel scenario for straw results in a lower climate impact regardless of the time horizon and method applied. This is in line with previous research on annual crops [30]. 
Table 4. Climate impact resulting from handling wheat straw in the biofuel scenario and the reference scenario. The climate impact is calculated for utilization of 200,000 t DM straw. Dark shading marks the scenario that results in higher climate impact.

\begin{tabular}{|c|c|c|c|c|c|c|}
\hline \multirow{2}{*}{ Time Horizon } & \multirow{2}{*}{ Climate-Impact Assessment } & \multirow{2}{*}{ Unit } & \multicolumn{2}{|c|}{ Biofuel Scenario } & \multicolumn{2}{|c|}{ Reference Scenario } \\
\hline & & & Low Case & High Case & Low Case & High Case \\
\hline \multirow{5}{*}{100 years } & GWP & $\mathrm{Mt} \mathrm{CO}_{2}$-eq. & 31 & 35 & 110 & 120 \\
\hline & GTP & $\mathrm{Mt} \mathrm{CO}$-eq. & 30 & 34 & 100 & 120 \\
\hline & $\mathrm{GWP}_{\text {bio }}$ & $\mathrm{Mt} \mathrm{CO}_{2}$-eq. & 31 & 35 & 110 & 120 \\
\hline & AGWP & $\mathrm{W} \times$ year $\times \mathrm{m}^{-2}$ & $1.1 \times 10^{-5}$ & $1.2 \times 10^{-5}$ & $3.5 \times 10^{-5}$ & $4.3 \times 10^{-5}$ \\
\hline & AGTP & $\mathrm{K}$ & $6.6 \times 10^{-8}$ & $6.8 \times 10^{-8}$ & $2.1 \times 10^{-7}$ & $2.5 \times 10^{-7}$ \\
\hline \multirow{5}{*}{20 years } & GWP & $\mathrm{Mt} \mathrm{CO}_{2}$-eq. & 34 & 38 & 110 & 130 \\
\hline & GTP & $\mathrm{Mt} \mathrm{CO}_{2}$-eq. & 33 & 37 & 110 & 130 \\
\hline & $\mathrm{GWP}_{\text {bio }}$ & $\mathrm{Mt} \mathrm{CO}_{2}$-eq. & 41 & 45 & 120 & 130 \\
\hline & AGWP & $\mathrm{W} \times$ year $\times \mathrm{m}^{-2}$ & $3.1 \times 10^{-6}$ & $3.2 \times 10^{-6}$ & $9.8 \times 10^{-6}$ & $1.2 \times 10^{-5}$ \\
\hline & AGTP & $\mathrm{K}$ & $8.5 \times 10^{-8}$ & $8.8 \times 10^{-8}$ & $2.7 \times 10^{-7}$ & $3.3 \times 10^{-7}$ \\
\hline
\end{tabular}

$\begin{array}{cccc}W \mathrm{y} \mathrm{m}^{-2} & \text { AGWP } & \mathrm{K} & \text { AGTP } \\ 5 \times 10^{-5} & & 4 \times 10^{-7} & \end{array}$

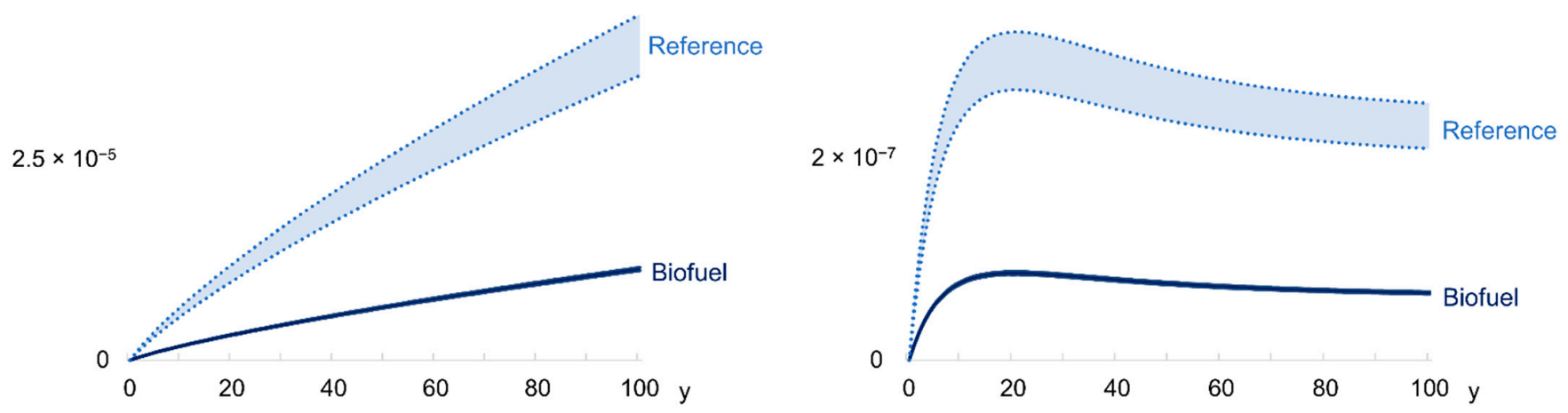

Figure 5. Climate impact in terms of AGWP (left) and AGTP (right) resulting from the handling of wheat straw in the biofuel scenario and the reference scenario. The climate impact is calculated for utilization of 200,000 t DM straw.

The time-dependent results in Figure 5 show that while the choice between AGWP and AGTP affects the magnitude of the resulting climate impact over time, it does not affect the comparison between the biofuel and reference scenario for straw. The characteristics of the results over time could be relevant if the straw is to be compared to another potential feedstock for biofuel, but such comparisons lie outside the scope of this study.

\subsection{Limitations and Uncertainty}

The parity times for the biofuel scenario for logging residues are context-specific and affected by several assumptions. Both the rotation time and the variables used to describe the rate of decay are based on local conditions, and therefore the ranges suggested in this study should not be considered generally applicable to bioenergy production from logging residues. The outcome of the comparison between biofuel and reference scenarios using different methods should rather be seen as indications of the importance of the choice of analytical approaches. This is in line with the aim of the present study to better understand how choices within the assessment method influence the comparison of the biofuel and reference scenarios.

The present calculations do not include any effects of the harvest of residues on the future productivity of forest or agricultural land. In Swedish forestry practice, the potential negative effects of harvesting residues are minimized by limiting the fraction available for harvest and, when appropriate, ash recycling [73]. In the case of straw, for which the biofuel scenario appears to be preferable regardless of the assessment method, the 
consequences in terms of future productivity of the agricultural land are not included, but such consequences are important when deciding on the management of straw. Therefore, the results presented for wheat straw should be interpreted as indicating less dependency on the analytical approaches discussed in this paper, and not that harvesting straw for biofuel production is always preferable to other management schemes.

In terms of time-related uncertainty, the static baselines for GHG concentrations in the atmosphere assumed in the GWP and GTP metrics, and the potential influence of climate change on biomass growth and decay constitute sources of uncertainty, especially in longer time frames. In this context, it should also be noted that the biofuel systems presented here do not represent optimized production processes, and environmental impacts other than climate change have not been considered. Therefore, the results and conclusions of this study should be complemented by other present and future studies.

\section{Conclusions}

The results show that different conclusions regarding the preferable scenario for logging residues (use as feedstock for bioethanol or leave to decay in the forest) can be drawn depending on how biogenic $\mathrm{CO}_{2}$ is included, the choice of time-horizon, and the choice of a cumulative or instantaneous metric for climate-impact. The inclusion of biogenic $\mathrm{CO}_{2}$ in time-dependent life-cycle inventories does not lead to a higher climate impact in the biofuel scenario, contrary to the results of applying the $\mathrm{GWP}_{\text {bio }}$ metric. Therefore, the existing $\mathrm{GWP}_{\text {bio }}$ factors could not be used as a single proxy for time-dependent modelling in the case of logging residues. The same method choices do however not affect the comparison between the biofuel and reference scenario for wheat straw, for which the biofuel scenario results in lower climate impact.

The added information from results displayed over time is highly relevant for logging residues as a biofuel feedstock, as the preferred scenario, in terms of climate impact, changes over time. Climate parity times range between approximately 25 and 95 years for the biofuel scenario in this study depending on the data used and on the choice of a cumulative or instantaneous climate impact metric. This is a consequence of the inclusion of biogenic $\mathrm{CO}_{2}$, and the immediate release of carbon to the atmosphere compared to slow degradation and release of the same carbon. It is therefore not affected by other aspects of forestry. Understanding the influence of how time dependent GHG fluxes are taken into account, and the chosen climate metric on results is thus important, also when only residual forest biomass is considered as feedstock for biofuels.

Furthermore, the difference between short- and long-term climate impact in LCA results can be better understood by expanding the discussion beyond the choice of timehorizon to also include the choice of instantaneous or cumulative climate impact metrics. For the case of logging residues, the results can be interpreted as more clearly indicating a lower climate impact for the biofuel scenario in the long term when the GTP metric is understood as a long-term indicator and GWP as a short-term indicator.

The scenarios for logging residues and wheat straw studied here highlight the importance of testing several method choices and climate impact assessment methods, especially for forest residual biomass, in order to provide a deeper understanding of the climate impact associated with residue-based biofuels. The parity times indicated for residual forest residual biomass and different types of climate impact may or may not be considered acceptable from a climate-change mitigation perspective, but enhancing the understanding of the method choices behind them could potentially aid in connecting them to specific climate mitigation strategies.

Supplementary Materials: The following are available online at https:/ /www.mdpi.com/article/ 10.3390/en14144219/s1, Supplementary Materials S1.

Funding: This research was funded by the Swedish Energy Agency, grant number 41251-1.

Institutional Review Board Statement: Not applicable. 
Informed Consent Statement: Not applicable.

Data Availability Statement: The data presented in this study are available in the present article and its Supplementary Materials.

Conflicts of Interest: The author declares no conflict of interest. The funder had no role in the design of the study; in the collection, analyses, or interpretation of data; in the writing of the manuscript, or in the decision to publish the results.

\section{References}

1. McManus, M.C.; Taylor, C.M. The changing nature of life cycle assessment. Biomass Bioenergy 2015, 82, 13-26. [CrossRef] [PubMed]

2. Lazarevic, D.; Martin, M. Life cycle assessment calculative practices in the Swedish biofuel sector: Governing biofuel sustainability by standards and numbers. Bus. Strategy Environ. 2018, 27, 1558-1568. [CrossRef]

3. EC. Directive (EU) 2018/2001 of the European Parliament and of the Council of 11 December 2018 on the Promotion of the Use of Energy from Renewable Sources; European Commission: Brussels, Belgium, 2018.

4. $\quad$ Finnveden, G.; Hauschild, M.Z.; Ekvall, T.; Guinée, J.; Heijungs, R.; Hellweg, S.; Koehler, A.; Pennington, D.; Suh, S. Recent developments in Life Cycle Assessment. J. Environ. Manag. 2009, 91, 1-21. [CrossRef] [PubMed]

5. McManus, M.C.; Taylor, C.M.; Mohr, A.; Whittaker, C.; Scown, C.D.; Borrion, A.L.; Glithero, N.J.; Yin, Y. Challenge clusters facing LCA in environmental decision-making-what we can learn from biofuels. Int. J. Life Cycle Assess. 2015, 20, 1399-1414. [CrossRef]

6. Lamers, P.; Junginger, M. The 'debt' is in the detail: A synthesis of recent temporal forest carbon analyses on woody biomass for energy. Biofuels Bioprod. Bioref. 2013, 7, 373-385. [CrossRef]

7. Kendall, A.; Chang, B.; Sharpe, B. Accounting for Time-Dependent Effects in Biofuel Life Cycle Greenhouse Gas Emissions Calculations. Environ. Sci. Technol. 2009, 43, 7142-7147. [CrossRef]

8. O'Hare, M.; Plevin, R.J.; Martin, J.I.; Jones, A.D.; Kendall, A.; Hopson, E. Proper accounting for time increases crop-based biofuels' greenhouse gas deficit versus petroleum. Environ. Res. Lett. 2009, 4, 024001. [CrossRef]

9. Cherubini, F.; Fuglestvedt, J.; Gasser, T.; Reisinger, A.; Cavalett, O.; Huijbregts, M.A.J.; Johansson, D.J.A.; Jørgensen, S.V.; Raugei, M.; Schivley, G.; et al. Bridging the gap between impact assessment methods and climate science. Environ. Sci. Policy 2016, 64, 129-140. [CrossRef]

10. Azar, C.; Johansson, D.J.A. On the relationship between metrics to compare greenhouse gases-The case of IGTP, GWP and SGTP. Earth Syst. Dynam. 2012, 3, 139-147. [CrossRef]

11. Farquharson, D.; Jaramillo, P.; Schivley, G.; Klima, K.; Carlson, D.; Samaras, C. Beyond Global Warming Potential: A Comparative Application of Climate Impact Metrics for the Life Cycle Assessment of Coal and Natural Gas Based Electricity. J. Ind. Ecol. 2017, 21, 857-873. [CrossRef]

12. Lueddeckens, S.; Saling, P.; Guenther, E. Temporal issues in life cycle assessment-A systematic review. Int. J. Life Cycle Assess. 2020, 25, 1385-1401. [CrossRef]

13. Beloin-Saint-Pierre, D.; Albers, A.; Hélias, A.; Tiruta-Barna, L.; Fantke, P.; Levasseur, A.; Benetto, E.; Benoist, A.; Collet, P. Addressing temporal considerations in life cycle assessment. Sci. Total Environ. 2020, 743, 140700. [CrossRef]

14. Zanchi, G.; Pena, N.; Bird, N. Is woody bioenergy carbon neutral? A comparative assessment of emissions from consumption of woody bioenergy and fossil fuel. GCB Bioenergy 2012, 4, 761-772. [CrossRef]

15. Norton, M.; Baldi, A.; Buda, V.; Carli, B.; Cudlin, P.; Jones, M.B.; Korhola, A.; Michalski, R.; Novo, F.; Oszlányi, J.; et al. Serious mismatches continue between science and policy in forest bioenergy. GCB Bioenergy 2019, 11, 1256-1263. [CrossRef]

16. Helin, T.; Sokka, L.; Soimakallio, S.; Pingoud, K.; Pajula, T. Approaches for inclusion of forest carbon cycle in life cycle assessmentA review. GCB Bioenergy 2013, 5, 475-486. [CrossRef]

17. Jolliet, O.; Antón, A.; Boulay, A.-M.; Cherubini, F.; Fantke, P.; Levasseur, A.; McKone, T.E.; Michelsen, O.; Milà i Canals, L.; Motoshita, M.; et al. Global guidance on environmental life cycle impact assessment indicators: Impacts of climate change, fine particulate matter formation, water consumption and land use. Int. J. Life Cycle Assess. 2018, 23, 2189-2207. [CrossRef]

18. Levasseur, A.; Cavalett, O.; Fuglestvedt, J.S.; Gasser, T.; Johansson, D.J.A.; Jørgensen, S.V.; Raugei, M.; Reisinger, A.; Schivley, G.; Strømman, A.; et al. Enhancing life cycle impact assessment from climate science: Review of recent findings and recommendations for application to LCA. Ecol. Indic. 2016, 71, 163-174. [CrossRef]

19. Brandão, M.; Levasseur, A.; Kirschbaum, M.U.F.; Weidema, B.P.; Cowie, A.L.; Jørgensen, S.V.; Hauschild, M.Z.; Pennington, D.W.; Chomkhamsri, K. Key issues and options in accounting for carbon sequestration and temporary storage in life cycle assessment and carbon footprinting. Int. J. Life Cycle Assess. 2013, 18, 230-240. [CrossRef]

20. Laganière, J.; Paré, D.; Thiffault, E.; Bernier, P.Y. Range and uncertainties in estimating delays in greenhouse gas mitigation potential of forest bioenergy sourced from Canadian forests. GCB Bioenergy 2017, 9, 358-369. [CrossRef]

21. Repo, A.; Tuomi, M.; Liski, J. Indirect carbon dioxide emissions from producing bioenergy from forest harvest residues. GCB Bioenergy 2011, 3, 107-115. [CrossRef]

22. Bentsen, N.S. Carbon debt and payback time-Lost in the forest? Renew. Sustain. Energy Rev. 2017, 73, 1211-1217. [CrossRef]

23. Hammar, T.; Stendahl, J.; Sundberg, C.; Holmström, H.; Hansson, P.-A. Climate impact and energy efficiency of woody bioenergy systems from a landscape perspective. Biomass Bioenergy 2019, 120, 189-199. [CrossRef] 
24. Hammar, T.; Levihn, F. Time-dependent climate impact of biomass use in a fourth generation district heating system, including BECCS. Biomass Bioenergy 2020, 138, 105606. [CrossRef]

25. Karlsson, H.; Ahlgren, S.; Sandgren, M.; Passoth, V.; Wallberg, O.; Hansson, P.-A. Greenhouse gas performance of biochemical biodiesel production from straw: Soil organic carbon changes and time-dependent climate impact. Biotechnol. Biofuels 2017, 10, 217. [CrossRef] [PubMed]

26. Sathre, R.; Gustavsson, L. Time-dependent climate benefits of using forest residues to substitute fossil fuels. Biomass Bioenergy 2011, 35, 2506-2516. [CrossRef]

27. Giuntoli, J.; Caserini, S.; Marelli, L.; Baxter, D.; Agostini, A. Domestic heating from forest logging residues: Environmental risks and benefits. J. Clean Prod. 2015, 99, 206-216. [CrossRef]

28. De Rosa, M.; Pizzol, M.; Schmidt, J. How methodological choices affect LCA climate impact results: The case of structural timber. Int. J. Life Cycle Assess. 2018, 23, 147-158. [CrossRef]

29. Cooper, S.J.G.; Green, R.; Hattam, L.; Röder, M.; Welfle, A.; McManus, M. Exploring temporal aspects of climate-change effects due to bioenergy. Biomass Bioenergy 2020, 142, 105778. [CrossRef]

30. Brandão, M.; Kirschbaum, M.U.F.; Cowie, A.L.; Hjuler, S.V. Quantifying the climate change effects of bioenergy systems: Comparison of 15 impact assessment methods. GCB Bioenergy 2019, 11, 727-743. [CrossRef]

31. Fargione, J.; Hill, J.; Tilman, D.; Polasky, S.; Hawthorne, P. Land Clearing and the Biofuel Carbon Debt. Science 2008, 319, 1235-1238. [CrossRef]

32. Searchinger, T.; Heimlich, R.; Houghton, R.A.; Dong, F.; Elobeid, A.; Fabiosa, J.; Tokgoz, S.; Hayes, D.; Yu, T.-h. Use of U.S. Croplands for Biofuels Increases Greenhouse Gases Through Emissions from Land-Use Change. Science 2008, 319, 1238-1240. [CrossRef] [PubMed]

33. Röder, M.; Thiffault, E.; Martínez-Alonso, C.; Senez-Gagnon, F.; Paradis, L.; Thornley, P. Understanding the timing and variation of greenhouse gas emissions of forest bioenergy systems. Biomass Bioenergy 2019, 121, 99-114. [CrossRef]

34. Campbell, B.M.; Beare, D.J.; Bennett, E.M.; Hall-Spencer, J.M.; Ingram, J.S.I.; Jaramillo, F.; Ortiz, R.; Ramankutty, N.; Sayer, J.A.; Shindell, D. Agriculture production as a major driver of the Earth system exceeding planetary boundaries. Ecol. Soc. 2017, 22. [CrossRef]

35. Eriksson, L.; Klapwijk, M.J. Attitudes towards biodiversity conservation and carbon substitution in forestry: A study of stakeholders in Sweden. For. Int. J. For. Res. 2019, 92, 219-229. [CrossRef]

36. Hanssen, S.V.; Huijbregts, M.A.J. Assessing the environmental benefits of utilising residual flows. Resour. Conserv. Recycl. 2019, 150, 104433. [CrossRef]

37. Hammar, T.; Ortiz, C.A.; Stendahl, J.; Ahlgren, S.; Hansson, P.-A. Time-Dynamic Effects on the Global Temperature When Harvesting Logging Residues for Bioenergy. BioEnergy Res. 2015, 8, 1912-1924. [CrossRef]

38. International Organization for Standardization (ISO). Environmental Management-Life Cycle Assessment-Requirements and Guidelines (ISO 14044:2006); ISO (International Organization for Standardization): Geneva, Switzerland, 2006.

39. Tonini, D.; Hamelin, L.; Astrup, T.F. Environmental implications of the use of agro-industrial residues for biorefineries: Application of a deterministic model for indirect land-use changes. Glob. Chang. Biol. Bioenergy 2016, 8, 690-706. [CrossRef]

40. Koponen, K.; Soimakallio, S.; Kline, K.L.; Cowie, A.; Brandão, M. Quantifying the climate effects of bioenergy-Choice of reference system. Renew. Sustain. Energy Rev. 2018, 81, 2271-2280. [CrossRef]

41. Biograce. Harmonised Calculations of Biofuel Greenhouse Gas Emissions in Europe. Version 4d; Institute for Energy and Environmental Research (IFEU): Heidelburg, Germany, 2015.

42. Edwards, R.; O'Connell, A.; Padella, M.; Giuntoli, J.; Koeble, R.; Bulgheroni, C.; Marelli, L.; Lonza, L. Definition of Input Data to Assess GHG Default Emissions from Biofuels in EU Legislation. Version 1d-2019; EUR 28349 EN; Publications Office of the European Union: Luxembourg, 2019.

43. Barta, Z.; Kovacs, K.; Reczey, K.; Zacchi, G. Process design and economics of on-site cellulase production on various carbon sources in a softwood-based ethanol plant. Enzym. Res. 2010, 2010, 1-8. [CrossRef]

44. Olofsson, J.; Barta, Z.; Börjesson, P.; Wallberg, O. Integrating enzyme fermentation in lignocellulosic ethanol production: Life-cycle assessment and techno-economic analysis. Biotechnol. Biofuels 2017, 10. [CrossRef]

45. Arvidsson, R.; Tillman, A.-M.; Sandén, B.A.; Janssen, M.; Nordelöf, A.; Kushnir, D.; Molander, S. Environmental Assessment of Emerging Technologies: Recommendations for Prospective LCA. J. Ind. Ecol. 2018, 22, 1286-1294. [CrossRef]

46. Karlsson, H. Climate Impact and Energy Balance of Emerging Biorefinery Systems. Ph.D. Thesis, Swedish University of Agricultural Sciences (SLU), Uppsala, Sweden, 2018.

47. Gilpin, G.S.; Andrae, A.S.G. Comparative attributional life cycle assessment of European cellulase enzyme production for use in second-generation lignocellulosic bioethanol production. Int. J. Life Cycle Assess. 2017, 22, 1034-1053. [CrossRef]

48. de la Fuente, T.; González-García, S.; Athanassiadis, D.; Nordfjell, T. Fuel consumption and GHG emissions of forest biomass supply chains in Northern Sweden: A comparison analysis between integrated and conventional supply chains. Scand. J. For. Res. 2017, 32, 568-581. [CrossRef]

49. Lantz, M.; Prade, T.; Ahlgren, S.; Björnsson, L. Biogas and Ethanol from Wheat Grain or Straw: Is There a Trade-Off between Climate Impact, Avoidance of iLUC and Production Cost? Energies 2018, 11, 2633. [CrossRef]

50. Levasseur, A.; Lesage, P.; Margni, M.; Samson, R. Biogenic Carbon and Temporary Storage Addressed with Dynamic Life Cycle Assessment. J. Ind. Ecol. 2013, 17, 117-128. [CrossRef] 
51. Albers, A.; Collet, P.; Benoist, A.; Hélias, A. Back to the future: Dynamic full carbon accounting applied to prospective bioenergy scenarios. Int. J. Life Cycle Assess. 2020, 25, 1242-1258. [CrossRef]

52. Holtsmark, B. Quantifying the global warming potential of CO2 emissions from wood fuels. GCB Bioenergy 2015, 7, 195-206. [CrossRef]

53. Yan, Y. Integrate carbon dynamic models in analyzing carbon sequestration impact of forest biomass harvest. Sci. Total Environ. 2018, 615, 581-587. [CrossRef]

54. Gustavsson, L.; Haus, S.; Ortiz, C.A.; Sathre, R.; Truong, N.L. Climate effects of bioenergy from forest residues in comparison to fossil energy. Appl. Energy 2015, 138, 36-50. [CrossRef]

55. Ågren, G.I.; Hyvönen, R.; Nilsson, T. Are Swedish forest soils sinks or sources for $\mathrm{CO}_{2}-$ Model analyses based on forest inventory data. Biogeochemistry 2007, 82, 217-227. [CrossRef]

56. Ortiz, C.A.; Liski, J.; Gärdenäs, A.I.; Lehtonen, A.; Lundblad, M.; Stendahl, J.; Ågren, G.I.; Karltun, E. Soil organic carbon stock changes in Swedish forest soils-A comparison of uncertainties and their sources through a national inventory and two simulation models. Ecol. Model. 2013, 251, 221-231. [CrossRef]

57. Ranius, T.; Hämäläinen, A.; Egnell, G.; Olsson, B.; Eklöf, K.; Stendahl, J.; Rudolphi, J.; Sténs, A.; Felton, A. The effects of logging residue extraction for energy on ecosystem services and biodiversity: A synthesis. J. Environ. Manag. 2018, 209, 409-425. [CrossRef] [PubMed]

58. Jurevics, A.; Peichl, M.; Egnell, G. Stand Volume Production in the Subsequent Stand during Three Decades Remains Unaffected by Slash and Stump Harvest in Nordic Forests. Forests 2018, 9, 770. [CrossRef]

59. Björnsson, L.; Prade, T. Sustainable cereal straw management-Use as feedstock for emerging biobased industries or cropland soil incorporation? Waste Biomass Valorization 2021. [CrossRef]

60. Buchspies, B.; Kaltschmitt, M.; Junginger, M. Straw utilization for biofuel production: A consequential assessment of greenhouse gas emissions from bioethanol and biomethane provision with a focus on the time dependency of emissions. GCB Bioenergy 2020, 12, 789-805. [CrossRef]

61. Myhre, G.; Shindell, D.; Bréon, F.-M.; Collins, W.; Fuglestvedt, J.; Huang, J.; Koch, D.; Lamarque, J.-F.; Lee, D.; Mendoza, B.; et al. Anthropogenic and Natural Radiative Forcing. In Climate Change 2013: The Physical Science Basis. Contribution of Working Group I to the Fifth Assessment Report of the Intergovernmental Panel on Climate Change; Stocker, T.F., Qin, D., Plattner, G.-K., Tignor, M., Allen, S.K., Boschung, J., Nauels, A., Xia, Y., Bex, V., Midgley, P.M., Eds.; Cambridge University Press: Cambridge, UK; New York, NY, USA, 2013; pp. 659-740.

62. Fuglestvedt, J.S.; Berntsen, T.K.; Godal, O.; Sausen, R.; Shine, K.P.; Skodvin, T. Metrics of Climate Change: Assessing Radiative Forcing and Emission Indices. Clim. Chang. 2003, 58, 267-331. [CrossRef]

63. Shine, K.P.; Fuglestvedt, J.S.; Hailemariam, K.; Stuber, N. Alternatives to the Global Warming Potential for Comparing Climate Impacts of Emissions of Greenhouse Gases. Clim. Chang. 2005, 68, 281-302. [CrossRef]

64. Cherubini, F.; Peters, G.P.; Berntsen, T.; Strømman, A.H.; Hertwich, E. $\mathrm{CO}_{2}$ emissions from biomass combustion for bioenergy: Atmospheric decay and contribution to global warming. GCB Bioenergy 2011, 3, 413-426. [CrossRef]

65. Guest, G.; Cherubini, F.; Strømman, A.H. The role of forest residues in the accounting for the global warming potential of bioenergy. GCB Bioenergy 2013, 5, 459-466. [CrossRef]

66. Liptow, C.; Janssen, M.; Tillman, A.-M. Accounting for effects of carbon flows in LCA of biomass-based products-Exploration and evaluation of a selection of existing methods. Int. J. Life Cycle Assess. 2018, 23, 2110-2125. [CrossRef]

67. Pingoud, K.; Ekholm, T.; Savolainen, I. Global warming potential factors and warming payback time as climate indicators of forest biomass use. Mitig. Adapt. Strateg. Glob. Chang. 2012, 17, 369-386. [CrossRef]

68. Ericsson, N.; Porsö, C.; Ahlgren, S.; Nordberg, Å.; Sundberg, C.; Hansson, P.-A. Time-dependent climate impact of a bioenergy system-Methodology development and application to Swedish conditions. GCB Bioenergy 2013, 5, 580-590. [CrossRef]

69. Faraca, G.; Tonini, D.; Astrup, T.F. Dynamic accounting of greenhouse gas emissions from cascading utilisation of wood waste. Sci. Total Environ. 2019, 651, 2689-2700. [CrossRef] [PubMed]

70. Levasseur, A.; Lesage, P.; Margni, M.; Deschênes, L.; Samson, R. Considering Time in LCA: Dynamic LCA and Its Application to Global Warming Impact Assessments. Environ. Sci. Technol. 2010, 44, 3169-3174. [CrossRef]

71. Cooper, S. Temporal Climate Impacts; University of Bath: Bath, UK, 2020. [CrossRef]

72. Allen, M. Short-Lived Promise? The Science and Policy of Cumulative and Short-Lived Climate Pollutants; Oxford Martin School, University of Oxford: Oxford, UK, 2015.

73. de Jong, J.; Akselsson, C.; Egnell, G.; Löfgren, S.; Olsson, B.A. Miljöpåverkan av Skogsbränsleuttag—En Syntes av Forskningsläget Baserat på Bränsleprogrammet Hållbarhet 2011-2016; ER 2018:02; The Swedish Energy Agency: Eskilstuna, Sweden, 2018. 